\title{
High Iridium concentration of alkaline rocks of Deccan and implications to $\mathrm{K} / \mathrm{T}$ boundary
}

\author{
P N Shukla, N Bhandari*, Anirban Das, A D Shukla and J S Ray \\ Physical Research Laboratory, Ahmedabad 380 009, India. \\ *e-mail: bhandari@prl.ernet.in
}

\begin{abstract}
We report here an unusually high concentration of iridium in some alkali basalts and alkaline rocks of Deccan region having an age of about 65Ma, similar to the age of the Cretaceous-Tertiary boundary. The alkali basalts of Anjar, in the western periphery of Deccan province, have iridium concentration as high as $178 \mathrm{pg} / \mathrm{g}$ whereas the alkaline rocks and basalts associated with the Amba Dongar carbonatite complex have concentrations ranging between 8 and $80 \mathrm{pg} / \mathrm{g}$. Some of these values are more than an order of magnitude higher than the concentration in the tholeiitic basalts of Deccan, indicating the significance of alkaline magmatism in the iridium inventory at the Cretaceous-Tertiary boundary. Despite higher concentration, their contribution to the global inventory of iridium in the Cretaceous-Tertiary boundary clays remains small. The concentration of iridium in fluorites from Amba Dongar was found to be $<30 \mathrm{pg} / \mathrm{g}$ indicating that iridium is not incorporated during their formation in hydrothermal activity.
\end{abstract}

\section{Introduction}

The voluminous Deccan flood basalts $(\geq 2 \times$ $10^{6} \mathrm{~km}^{3}$ ), because of their peak activity of eruption around the same time as the Cretaceous-Tertiary transition (65Ma ago), are considered to have been responsible for the mass extinction (McLean 1985; Courtillot et al 1986). The extinction event is associated with a high concentration of platinum group elements, specially iridium in the $\mathrm{K} / \mathrm{T}$ boundary (KTB) clays which, at places, is found in concentrations as high as $>100 \mathrm{ng} / \mathrm{g}$, although the global average value is about $10 \mathrm{ng} / \mathrm{g}$. This is more than two orders of magnitude higher than the iridium concentration found in other marine sediments, and therefore an extraterrestrial source such as asteroidal or cometary bolide has been invoked as a source of the high iridium concentration at the K/T boundary (Alvarez et al 1980; Hut et al 1987). Systematic measurements of iridium in Deccan basalts have not been made, but a few analyses of tholeiites have shown that they typically have low concentrations (about $10 \mathrm{pg} / \mathrm{g}$ ). This is taken to indicate that their contribution to the iridium inventory at the KTB (Orth et al 1990; Bhandari et al 1993) is negligible, thus favoring an extraterrestrial source.

Apart from tholeiitic basalts, which constitute the bulk $(\sim 99 \%)$ of Deccan, numerous though minor regions of alkali basalts, carbonatitic and acidic rocks are known to occur; they have not been analyzed for PGE and their iridium contribution at KTB is not known. This has become an important aspect, since iridium rich sediments have been found sandwiched between basaltic flows at Anjar (Bhandari et al 1995), most of which are alkaline.

In general, alkaline magmatism in Deccan is confined to the western and northwestern part of the Indian shield and is particularly clustered around the Gulf of Cambay (Saurashtra and Kutch), localized in plug-like bodies along belts in the Narmada-Son fracture zone (Bose 1980). We have now measured the iridium concentration in some alkaline and carbonatitic rocks of Deccan. Two suites of rocks, having formation ages close to the $\mathrm{K} / \mathrm{T}$ boundary were selected for this work. The first set consisted of the basalt flow sequence at Anjar in Kutch (Bhandari et al 1995, 1996) and the second suite of rocks were taken from the Amba Dongar carbonatite complex (Viladkar 1996).

Keywords. Carbonatite; Deccan; iridium; alkaline rocks; K/T boundary; Anjar; Amba Dongar.

Proc. Indian Acad. Sci. (Earth Planet. Sci.), 110, No. 2, June 2001, pp. 103-110

(C) Printed in India. 

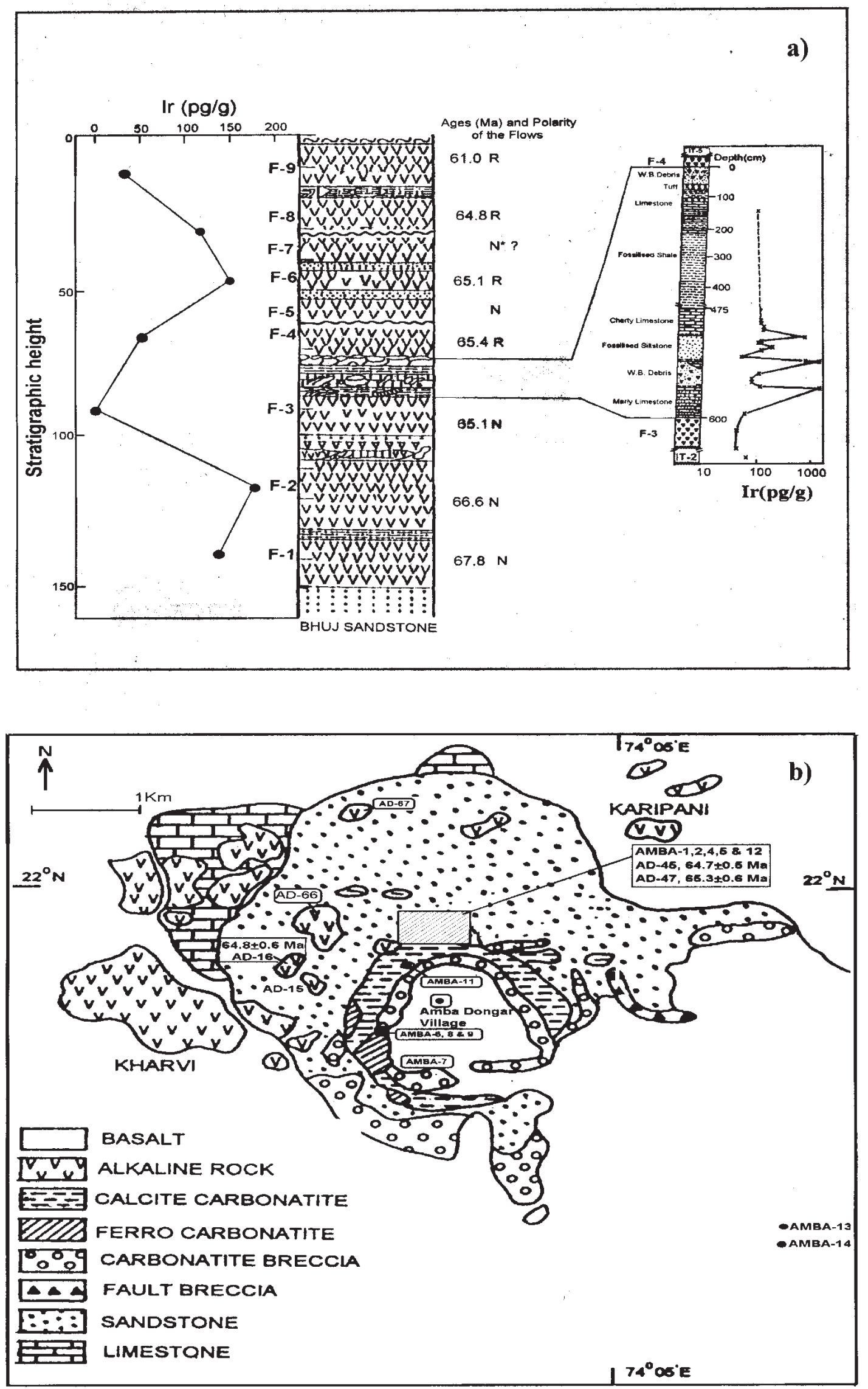

Figure 1. (a) Composite litholog of the Anjar volcano-sedimentary sequence showing ages, magnetic polarity and iridium profile in basalts (left) and the third intertrappean sedimentary bed (right). (b) Amba Dongar Alkaline complex (after Viladkar 1996) showing sample locations and ages of rocks (in Ma) (after Ray and Pande 1999). 
Table 1. Concentration of some elements in the Anjar flows.

\begin{tabular}{|c|c|c|c|c|c|c|c|c|c|c|c|}
\hline Flow & $\#$ & Nature & $\begin{array}{l}\text { Ages } \\
(\mathrm{Ma})\end{array}$ & $\begin{array}{l}\mathrm{Fe} \\
(\%)\end{array}$ & $\begin{array}{c}\operatorname{Ir} \\
(\mathrm{pg} / \mathrm{g})\end{array}$ & $\begin{array}{c}\mathrm{Cr} \\
(\mu \mathrm{g} / \mathrm{g})\end{array}$ & $\begin{array}{c}\mathrm{Co} \\
(\mu \mathrm{g} / \mathrm{g})\end{array}$ & $\begin{array}{l}\mathrm{SiO}_{2} \\
(\%)\end{array}$ & $\begin{array}{l}\mathrm{Na}_{2} \mathrm{O} \\
(\%)\end{array}$ & $\begin{array}{l}\mathrm{K}_{2} \mathrm{O} \\
(\%)\end{array}$ & $\begin{array}{c}\text { Alkalinity } \\
\text { index* }\end{array}$ \\
\hline \multirow[t]{2}{*}{ F9 } & (AJ6-3) & Tholeiitic & 61 & 9.27 & 33 & 128 & 52.0 & 45.78 & 2.19 & 0.17 & 0.052 \\
\hline & (KP7) & & & 9.64 & 26 & 125 & 53.0 & 45.99 & 2.22 & 0.15 & 0.052 \\
\hline \multirow[t]{2}{*}{ F8 } & (HS) & Transitional & 64.8 & 7.75 & 108 & 27.2 & 31.3 & - & 3.08 & - & - \\
\hline & (KP6) & Transitional & & 8.80 & 124 & 28.8 & 31.9 & 51.84 & 3.14 & 1.66 & 0.093 \\
\hline F6 & (AJ8-4) & Transitional & 65.1 & 8.81 & 151 & 22 & 32.5 & 52.37 & 3.07 & 1.41 & 0.086 \\
\hline $\mathrm{F} 4$ & (AJ4-5) & Transitional & 65.4 & 10.2 & 50 & 113 & 43.3 & 49.78 & 2.7 & 1.03 & 0.075 \\
\hline \multirow[t]{2}{*}{ F3 } & $(\# 32)$ & Alkaline & 65.1 & 9.1 & 2.2 & 8.57 & 45.7 & 45.73 & 2.5 & 1.13 & 0.079 \\
\hline & & & & & & & & & 1.44 & & \\
\hline \multirow[t]{2}{*}{$\mathrm{F} 2$} & (AJ 1-10) & Highly & 66.6 & 12.5 & 178 & 82.3 & 59.8 & 45.11 & 3.08 & 1.68 & 0.106 \\
\hline & & alkaline & & & & & & & 3.45 & & \\
\hline $\mathrm{F} 1$ & (AJ11-13) & $\begin{array}{l}\text { Highly } \\
\text { alkaline }\end{array}$ & 67.8 & 11.0 & 139 & 43.5 & 49.9 & 45.16 & 2.85 & 1.68 & 0.100 \\
\hline
\end{tabular}

*Alkalinity index defined as $\left(\mathrm{Na}_{2} \mathrm{O}+\mathrm{K}_{2} \mathrm{O}\right) / \mathrm{SiO}_{2}$.

\section{Geological settings and geochronological framework}

\subsection{Anjar Volcano-sedimentary sequence}

The Anjar volcano-sedimentary sequence consists of nine basalt flows, some of which are separated by several meters thick sedimentary deposits (figure 1a). The basalts, dated by ${ }^{40} \mathrm{Ar}-{ }^{39} \mathrm{Ar}$ method, span an age bracket of about 61.6 to $\sim 67.8 \mathrm{Ma}$ (Venkatesan and Pande, private communication 1996). However, the four flows (F-3, 4, 6 and 8) are found to have an age close to $65 \pm 1 \mathrm{Ma}$ (Venkatesan et al 1996; Venkatesan and Pande, private communication), same as the age of KTB (Izett et al 1991). The lowermost flow (F-1) has an age of $\sim 68 \mathrm{Ma}$ indicating that the Deccan activity in Kutch started well before the $\mathrm{K} / \mathrm{T}$ event. The age of the uppermost flow (F-9) is not known precisely because the apparent age spectrum did not yield a plateau; however the data suggest a value of about $62 \mathrm{Ma}$. The primary reversed magnetic polarity of flows F-4, 6 and 8, which could be determined with confidence, places them in the magnetic chron 29R, during which the iridium-rich KTB layer was deposited (Shukla et al 2001). The sediments in the third intertrappean bed (IT3) which is about 5.8 meters thick near Viri show high concentration of iridium, having values generally about $100 \mathrm{pg} / \mathrm{g}$. About 1.2 meters above the lower flow (F-3), it also contains three horizons (figure 1a), separated by about 25 and $32 \mathrm{cms}$ respectively, which show enriched concentration of iridium (700 to 1333 $\mathrm{pg} / \mathrm{g}$ ) and osmium (1215 to $2230 \mathrm{pg} / \mathrm{g}$ ). Based on the chronology of basalts (65 Ma), chemical composition (high iridium, osmium) and fossil records (Ghevariya 1988; Bajpai and Prasad 2000), it has been inferred that these three layers were deposited at or close to the $\mathrm{K} / \mathrm{T}$ boundary (Bhandari et al 1995, 1996). Based on their chemical composition, flows 1 to 8 can be classified as Ocean Island alkali basalts (OIB) and F-9 is similar to the uncontaminated basalts of Ambenali (Shukla et al 2001). Samples of seven of these nine basalt flows have been analyzed in the present study (table 1 ).

\subsection{Amba Dongar complex}

The Amba Dongar alkaline complex in Chota Udaipur is a subvolcanic intrusion with some explosive activity, which intruded the pre-existing basalts and Bagh sandstones of Cretaceous age (Viladkar 1996). The complex is about $30 \mathrm{sq} . \mathrm{km}$. in area and is in the form of a ring dyke, wherein fenite is formed by alkalic metasomatism of the Bagh sandstones (figure 1b). The complex has been dated by ${ }^{40} \mathrm{Ar}-{ }^{39} \mathrm{Ar}$ method and found to be 65.0 0.3 Ma old (Ray 1997; Ray and Pande 1999). Phlogopite from calcite carbonatites gives an age of $65.5 \pm 0.8 \mathrm{Ma}$ whereas the nephelenites that are exposed in the lower areas are dated at $64.8 \pm 0.6$ Ma. The similarity of ages suggests that the nephelenitic and carbonatitic volcanisms are contemporaneous. In the center of the complex, there is a much younger basaltic intrusion (Viladkar 1996). Majority of the alkaline/carbonatite-alkaline complexes such as at Phenai mata and Bhakatgarh in Deccan have also been emplaced synchronously with Amba Dongar at 65Ma (Ray and Pande 1999). This synchroneity and the tremendous fluid bearing capacity of such magmas have led to the suggestion that they have played a role in the $\mathrm{K} / \mathrm{T}$ mass extinction. For example, the carbonatitealkaline activity could have injected catastrophic 
Table 2. Concentration of some elements in rocks of Amba Dongar carbonatite complex determined by NiS bead fire assay method following NAA.

\begin{tabular}{llccccccc}
\hline Sample & Nature & $\mathrm{Ir}(\mathrm{pg} / \mathrm{g})$ & $\mathrm{Ru}(\mathrm{ng} / \mathrm{g})$ & $\mathrm{Ag}(\mathrm{ng} / \mathrm{g})$ & $\mathrm{Se}(\mathrm{ng} / \mathrm{g})$ & $\mathrm{Co}(\mu \mathrm{g} / \mathrm{g})$ & $\mathrm{Cr}(\mu \mathrm{g} / \mathrm{g})$ & $\mathrm{Fe}(\%)$ \\
\hline A-45 & Ca-Tinguaite & $<8$ & 465 & 37.7 & 110 & 9.79 & 5.05 & 6.25 \\
A-47 & Ca-Tinguaite & $6.8 \pm 0.4$ & 163 & 36.2 & 120 & 15.1 & 9.33 & 3.98 \\
A-1 & Mineralised & $51 \pm 4$ & 2389 & 129 & 310 & 2.60 & 34.7 & 1.15 \\
& Carbonatite & & & & & & & \\
A-5 & Ferro Carbonatite & $<26$ & 593 & 140 & 180 & 6.15 & 33.9 & 4.65 \\
A-6 & Ferro Carbonatite & $7.6 \pm 2$ & 40 & 15.8 & 600 & 1.66 & 33.4 & 3.40 \\
A-8 & Banded Ferro & $<14$ & 433 & 118 & 1750 & 1.71 & 48.6 & 18.6 \\
& Carbonatite & & & & & & & \\
A-9 & Ferro Carbonatite & $<25$ & 302 & 101 & 360 & 5.21 & 38.9 & 10.7 \\
A-4 & Fenite & $20.6 \pm 3$ & 99 & 246 & 40 & 9.51 & 89.5 & 3.40 \\
A-15 & Nephelenite & $18 \pm 0.5$ & 806 & 74.9 & 40 & 11.4 & 13.1 & 7.23 \\
A-66 & Nephelenite & $13.3 \pm 3.6$ & 1904 & 50.6 & 90 & 5.95 & 18.7 & 6.07 \\
A-13 & Tuff & $16.5 \pm 2.5$ & 551 & 43.1 & 45 & 9.84 & 14.1 & 3.70 \\
A-2 & Black coating & $158 \pm 13$ & 1070 & 352 & 25 & 335 & 15.4 & 1.38 \\
A-12 & Inner basalt & $<20$ & 58 & 55.5 & 160 & 47.3 & 104 & 7.78 \\
A-14-I & Outer basalt & $74 \pm 4$ & 220 & 37.2 & 80 & 45.6 & 15.5 & 9.80 \\
A-14-II & Outer basalt & $73 \pm 7$ & 270 & 35.4 & 90 & 40.6 & 16.5 & 10.5 \\
& Fluorites* & $<30$ & - & - & - & $0-0.28$ & $0-5.5$ & $0-0.08$ \\
Error & & & 7 & 10 & 4 & 1 & 2 & 1 \\
$1 \sigma(\%)$ & & & & & & & & \\
\hline
\end{tabular}

${ }^{*}$ Based on analysis of seven samples.

amounts of $\mathrm{CO}_{2}$ and $\mathrm{SO}_{2}$ in a very short time of a few years into the atmosphere thereby aggravating or even triggering the extinction events at the KTB (Ray and Pande 1999).

Samples of various types of carbonatites, basalts, alkaline rocks and fluorite crystals (table 2) were collected at locations shown in figure 1(b). Basalts from outside the ring dyke (outer basalts) and from the center of the complex (inner basalts) are included in the analysis. The deposits of fluorite in Amba Dongar are concentrated mostly in sövite (calcitic carbonatite) and also along the contact of Bagh sandstone. Some of the carbonatite blocks had a black fine coat, presumably due to some postformation physico-chemical processes. This is also included in the analysis.

\section{Analytical techniques}

Elemental concentrations were determined by the instrumental neutron activation analysis (INAA) technique following the procedure described elsewhere (Bhandari et al 1994). Concentration of several elements (Fe, Co, Ni, Cr, Ca, Ba, Th, Se, Hf, $\mathrm{Sb}, \mathrm{Na}, \mathrm{K}$ etc.) and nine rare-earth elements (REE: $\mathrm{La}, \mathrm{Ce}, \mathrm{Nd}, \mathrm{Sm}, \mathrm{Eu}, \mathrm{Gd}, \mathrm{Tb}, \mathrm{Yb}$ and $\mathrm{Lu}$ ) could be determined in this way. Concentrations of Ir was determined after radiochemical separation following a procedure adopted from Keays et al (1974) or by the NiS fire assay technique developed by Schmidt and Pernicka (1994). However, in order to minimize contamination and also to measure all the elements mentioned above, we have concentrated Ir in NiS bead after irradiation with thermal neutrons (Das and Shukla 1999) and not before irradiation as was done by Schmidt and Pernicka (1994). The iridium concentrations determined by RNAA and NiS fire assay method agreed within errors except for a few samples in which the difference ranged up to $\pm 18 \%$. Because of the possibility that a part of this variation could be due to sample heterogeneity, we have used the mean values in the following discussion.

\section{Results and discussion}

The concentrations of some selected elements measured in Anjar basalts are given in table 1. The iridium concentration in Anjar flows 1, 2, 4, 6 and 8 (50 to $178 \mathrm{pg} / \mathrm{g}$ ) is more than an order of magnitude higher than that found in tholeiites of Deccan whereas Flows 3 and 9 show lower concentration of Ir (2.2 to $\sim 30 \mathrm{pg} / \mathrm{g})$, similar to that found in tholeiites. The flows 3 and 4, between which the third intertrappean bed is sandwiched 


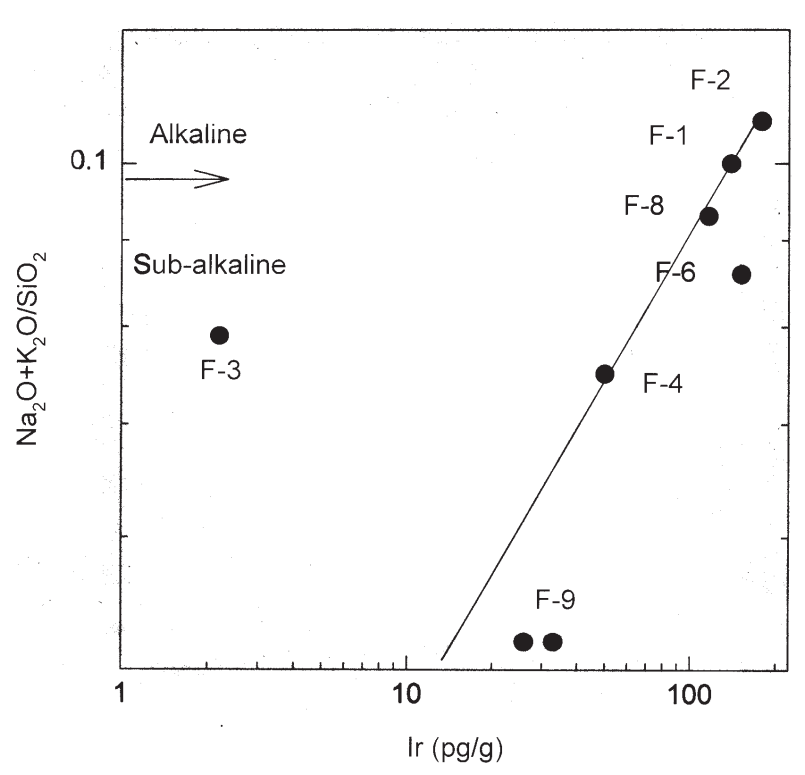

Figure 2(a). Correlation of iridium concentration with alkalinity index in Anjar basalts.

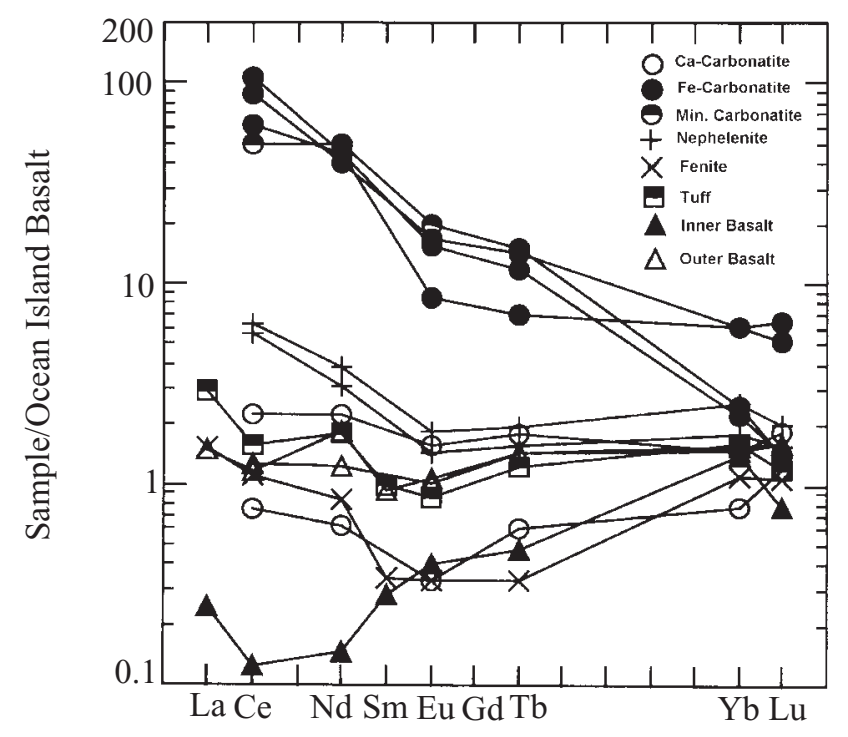

Figure 2(b). Rare earth patterns of different samples of carbonatite, alkaline rocks, fenites and fluorites of Amba Dongar normalised to Ocean Island Alkali Basalts (OIAB).

have low concentrations of iridium (2.2 and 50 $\mathrm{pg} / \mathrm{g}$ ) and it is unlikely that they could have given rise to the iridium enhancement (up to $1333 \mathrm{pg} / \mathrm{g}$ ) seen in the intervening sediments. The basalts F1 through F-8 are alkaline in nature, resembling Ocean Island basalts (OIB), different from most tholeiites whereas F-9 is similar to the uncontaminated Ambenali tholeiitic basalt (Shukla et al 2001). The high iridium concentration in Anjar basalts are comparable to the iridium concentration in the Hawaiian (Kilauea) alkali basalts (320 $\mathrm{pg} / \mathrm{g}$ ) and may be due to the nature of the magma, related to the original reservoir of the Réunion hot spot from which the lava is believed to have been derived. Figure 2(a) shows that iridium concentration in all the basalts (except F-3) has a reasonable correlation with alkalinity index $\left(\mathrm{Na}_{2} \mathrm{O}+\right.$ $\left.\mathrm{K}_{2} \mathrm{O}\right) / \mathrm{SiO}_{2}$. As rocks associated with carbonatites in the Amba Dongar complex are also alkaline, we have measured several elements including iridium in them. The concentrations of some selected elements in Amba Dongar rocks are given in table 2 . These rocks are very heterogeneous and concentrations of trace elements vary significantly in different phases (Viladkar 1996). The REE patterns, normalized to Ocean Island basalts are shown in figure 2(b). The nearly flat pattern indicates that, like Anjar, Amba Dongar outer basalt also belongs to the OIB group. The concentration of iridium in the younger inner basalt had no measurable amount of $\operatorname{Ir}(<20 \mathrm{pg} / \mathrm{g})$ but the outer basalt was found to have around $74 \mathrm{pg} / \mathrm{g}$. This high value was confirmed by a replicate measurement (table 2 ). The iridium concentration in other alkaline rocks is in the range of 6.8 to $18 \mathrm{pg} / \mathrm{g}$ but some ferro carbonatites in which reliable measurements could be made have lower concentrations, $\sim 8 \mathrm{pg} / \mathrm{g}$. The mineralised carbonatite A-1 however has marginally high concentration $(51 \mathrm{pg} / \mathrm{g})$ and fenites, which are formed due to metasomatisation of the pre-existing Bagh Sandstones, have 21pg Ir/g. Fluorite mineralisation in the Amba Dongar area is the result of F-rich hydrothermal deposition associated with the carbonatitic magma (Sukheswala and Udas 1964) marking the end phase of carbonatite activity (Viladkar 1996). It has been suggested that chloride and fluoride rich liquids might cause mobilisation of PGE (Wood 1987). In the presence of fluorine, iridium is expected to form the volatile $\mathrm{IrF}_{6}$ (melting point $44.4^{\circ} \mathrm{C}$; boiling point $53^{\circ} \mathrm{C}$ ). Zoller et al (1983) observed that iridium emissions from Kilauea volcano were related to the fluorine content of the magma and high volatility of $\mathrm{IrF}_{6}$ led them to suggest that iridium may be transported as gaseous $\mathrm{IrF}_{6}$ in volcanic emissions. Toutain and Meyer (1989) also found high concentration of Ir in low temperature volcanic sublimates. The temperature of the hydrothermal fluid in Amba Dongar has been estimated to be 100 to $200^{\circ} \mathrm{C}$ from the fluid inclusion studies (Roedder 1973). Our analysis shows that the fluorites are mainly calcium fluorides $(\mathrm{Ca}=31-51 \%)$ having high $\mathrm{Ba}$ (8ppm to $1 \%)$ and rare earths. Concentration of Ir in fluorites is found to be $\leq 30 \mathrm{pg} / \mathrm{g}$ (table 2). If all the iridium of the fluorine-rich hydrothermal fluid is assumed to be incorporated in the fluorites, then it can be concluded that iridium occurs in small concentration levels in the hydrothermal fluid. This is consistent with the thermodynamic calculations of Wood (1987) which suggested that iridium hexafluoride is unstable in the presence of water. The 
concentration of Os in all the rocks is below the detection limit of $200 \mathrm{pg} / \mathrm{g}$. Apart from the results related to iridium, the data suggest several interesting correlations. The concentrations of iridium and ruthenium (as well as silver) roughly correlate in carbonatites as well as in alkali basalts. Iridium in Anjar basalts seems to correlate well with copper. This supports the observation of Toutain and Meyer (1989) that high iridium concentrations occur in volcanic sublimates containing mitscerlichite $\left(\mathrm{K}_{2} \mathrm{Cu} \mathrm{Cl} \mathrm{Cl}_{4} .2 \mathrm{H}_{2} \mathrm{O}\right)$. Ir does not correlate with any other element i.e. V, Co, Ni, Mn, Sr, Lu, Eu, $\mathrm{Fe}, \mathrm{Al}$ or Si measured here. The coating on rocks (A-2) seems to have the highest iridium concentration (158 $\pm 13 \mathrm{pg} / \mathrm{g})$ which should have concentrated on the surface by some physico-chemical process.

\section{Iridium contribution from Deccan volcanism}

The results discussed above suggest a high concentration of iridium in alkali basalts of Anjar as well as Amba Dongar but low concentration in all other rocks. Orth et al (1990) measured the iridium concentration ranging between 6 and $26 \mathrm{pg} / \mathrm{g}$ in six Deccan tholeiites. These values are consistent with the concentration $(<27 \mathrm{pg} / \mathrm{g})$ estimated by us in a few basalts from Takli and other locations in Deccan (Bhandari et al 1993, 1996). Based on their measurements, Orth et al (1990) adopted an average concentration (c) of $3.2 \mathrm{pg} / \mathrm{g}$ and calculated the maximum contribution $\left(\mathrm{D}_{\text {Ir }}\right)$ of Deccan volcanism to the global iridium inventory in the KTB clays, using the relation:

$$
\mathrm{D}_{\text {Ir }}=\mathrm{c} \times \mathrm{V} \times \rho \times \mathrm{F}_{65} \times \mathrm{F}_{\mathrm{atm}}
$$

where $V=$ volume of Deccan, estimated to be $\sim 2 \times 10^{6} \mathrm{~km}^{3}, \rho=$ density $\left(\sim 3 \mathrm{~g} / \mathrm{cm}^{3}\right), F_{65}$ is the volume fraction of Deccan basalts formed at $\mathrm{KTB}($ at $65 \mathrm{Ma}), F_{\text {atm }}=$ fraction of iridium going into the atmosphere, usually taken as $0.3 \%$, based on the measurements of Olmez et al (1986) on the Hawaiian basalts and airborne volcanic emissions. The value $F_{65}$ is not known. Arguments have been developed based on magnetic polarity and ages of rocks that the peak Deccan activity had a duration of $<1 \mathrm{Ma}$ around $65 \mathrm{Ma}$ (Courtillot et al 1988, Allègre et al 1999). However the ${ }^{40} \mathrm{Ar}-{ }^{39} \mathrm{Ar}$ ages of the Deccan flows reveal that the volcanism lasted from 69-63 Ma and bulk of the lavas erupted at $67 \mathrm{Ma}$ (Venkatesan et al 1993; Venkatesan and Pande 1996). The frequency distribution of ${ }^{40} \mathrm{Ar}_{-}{ }^{39} \mathrm{Ar}$ ages plotted with stratigraphic height indicates that the Deccan activity peaked at $67 \mathrm{Ma}$ (Pande and Venkatesan, private communication). Recently Allègre et al (1999) have dated a few samples from Deccan traps around Nagpur, Dongargaon and Igatpuri etc. by Re-Os method and found that all of them fall on an isochron corresponding to an age of $65.6 \pm 0.3 \mathrm{Ma}$ and osmium data imply a short duration of volcanism. Here we adopt a value of $22 \%$ for $\mathrm{F}_{65}$, being the fraction of flows having ages between 64.5 and 65.5 Ma based on the age distribution given by Pande and Venkatesan (private communication). Even if the maximum value of $100 \%$ is taken, the conclusions discussed below will not change. Taking these values, the global contribution of iridium by Deccan volcanism is estimated to be about 13 tons. The global iridium inventory in the KTB clays is estimated, based on the mean global value of integrated vertical profile of iridium of $50 \mathrm{ng} / \mathrm{cm}^{2}$ to be about 250,000 tons. Thus, the Deccan contribution falls short by over four orders of magnitude compared to the iridium inventory in the KTB layer, in agreement with several such calculations (Bhandari et al 1993; Orth et al 1990), necessitating an extraterrestrial source. If we adopt concentration of $100 \mathrm{pg} \mathrm{Ir} / \mathrm{g}$, the mean value of Anjar basalts, as typical of alkali basalts in Deccan, the iridium contribution due to alkali basalts is estimated to be $\leq 10 \%$ of the whole of Deccan since volumetrically the alkali basalts constitute less than about $1 \%$ of the Deccan. The global contribution due to Deccan thus remains negligible. However, the alkali basalts can possibly make some contribution locally, e.g. within the Deccan province. We therefore investigated if the alkali basalts can give rise to anomalies seen in Anjar intertrappeans where concentrations as high as 600 to $1200 \mathrm{pg} / \mathrm{g}$ iridium have been found in three thin layers (Bhandari et al 1995). Integrating the vertical profile of iridium in the third intertrappean bed of Anjar, we estimate a fallout of $10,000 \mathrm{pg} / \mathrm{cm}^{2}$. Taking the area of Amba Dongar carbonatites as $30 \mathrm{sq} \mathrm{km}$ and a thickness of $1 \mathrm{~km}$, the iridium contribution works out to be only about $30 \mathrm{pg} / \mathrm{cm}^{2}$, at Anjar situated about 500 $\mathrm{km}$ away if the iridium is distributed uniformly and $F_{\text {atm }}$ has a value similar to the one adopted above $(0.3 \%) . F_{\text {atm }}$ for carbonatitic magma is, however, not known and, in view of its low viscosity and high gas content, could be large. For Amba Dongar and other carbonatites to contribute significantly to the Anjar iridium enhancement, $F_{\text {atm }}$ has to be nearly $100 \%$. Since Amba Dongar formation is sub-volcanic, it is unlikely that iridium and other volatiles present in these rocks have been completely lost to the atmosphere. Therefore, the iridium enhancements at Anjar could not have been caused by alkaline complexes in Amba Dongar. Similar arguments can be made for other, smaller alkaline bodies in Saurashtra. We therefore conclude that iridium enhancement seen in the Anjar intertrappeans can not arise from the alkali 
complexes of the Deccan. This argument is further strengthened since high iridium concentration $(>120 \mathrm{pg} / \mathrm{g})$ has not been observed widely in the Deccan intertrappean sediments (except at Anjar) (Bhandari et al 1993). We, therefore, infer that the carbonatites and alkaline complexes have contributed little iridium at the $\mathrm{K} / \mathrm{T}$ boundary locally, and less so in the global $\mathrm{K} / \mathrm{T}$ layer.

Our analyses, thus, allow us to determine the contribution of alkali basalts of Anjar as well as of Amba Dongar carbonatite complex in the iridium budget in the $\mathrm{K} / \mathrm{T}$ boundary clays. In spite of their high concentration, the contribution of alkali basalts and Deccan as a whole is small and an extraterrestrial source is required to explain the global inventory of iridium at the KT boundary.

\section{Acknowledgement}

We thank Drs. K Pande and T R Venkatesan for allowing us to use their unpublished dates of the Anjar sequence and their frequency distribution of ages of the Deccan flows.

\section{References}

Allègre C J, Birck J L, Capmas F and Courtillot V 1999 Age of the Deccan traps using ${ }^{187} \mathrm{Re}^{187}$ Os systematics; Earth Planet. Sci. Lett. 170 197-204

Alvarez L W, Alvarez W, Asaro F and Michel H V 1980 Extraterrestrial cause for the Cretaceous-Tertiary extinction; Science 208 1095-1108

Bajpai S and Prasad G V R 2000 Cretaceous age for Ir-rich Deccan intertrappean deposits: paleontological evidence from Anjar, western India; J. Geol. Soc. London $107257-$ 260

Bhandari N, Gupta M, Pandey J and Shukla P N 1994 Chemical profiles in K/T Boundary section of Meghalya, India: cometary, asteroidal or volcanic; Chem. Geol. 113 $45-60$

Bhandari N, Gupta M and Shukla P N 1993 Deccan volcanic contribution of Ir and other trace elements near the $\mathrm{K} / \mathrm{T}$ boundary; Chem. Geol. 103 129-139

Bhandari N, Shukla P N, Ghevariya Z G and Sundaram S M 1995 Impact did not trigger Deccan volcanism: Evidence from Anjar K/T boundary intertrappean sediments; Geophys. Res. Lett. 22 433-436

Bhandari N, Shukla P N, Ghevariya Z G and Sundaram S M $1996 \mathrm{~K} / \mathrm{T}$ boundary layer in Deccan intertrappeans at Anjar, Kutch; Geol. Soc. Am. Spec. Pap. 307 417-424

Bose M K 1980 Alkaline magmatism in the Deccan volcanic province; J. Geol. Soc. India, 21 317-329

Courtillot V, Besse J, Vandamme D, Montigny R, Jaeger J J and Cappetta H 1986 Deccan flood basalts at the Cretaceous-Tertiary boundary; Earth Planet. Sci. Lett. 80 361-374

Courtillot V, Feraud G, Maluski H, Vandamme D, Moreau M G, Besse J, 1988 Deccan flood basalts and the Cretaceous/Tertiary boundary; Nature, 333 843-846
Das A and Shukla A D 1999 A rapid NiS bead technique for measurements of picogram concentrations of platinum group elements (PGEs) following neutron activation: In Proc. Nuclear and Radiochemistry symposium (NUCAR 99), Bhabha Atomic Research Center, Mumbai 321-322

Ghevariya Z G 1988 Intertrappean dinosaurian fossils from Anjar area, Kutch district, Gujarat; Current Science $\mathbf{5 7}$ 248-251

Hut P, Alvarez W, Elder W P, Hansen T, Kauffman E G, Keller G, Shoemaker E M and Weissman P R 1987 Comet showers as a cause of mass extinctions; Nature 329118 126

Izett G A, Dalrymple G B and Snee L W $1991{ }^{40} \mathrm{Ar}^{39}{ }^{39} \mathrm{Ar}$ age of Cretaceous-Tertiary boundary tektites from Haiti; Science 252 1539-1542

Keays R R, Ganapathy R, Laul J C, Krähenbühl U and Morgan J W 1974 The simultaneous determination of 20 trace elements in terrestrial, lunar and meteoritic material by radio-chemical neutron activation analysis; Anal. Chim. Acta 72 1-24

McLean D M 1985 Deccan traps mantle degassing in the terminal Cretaceous marine extinction; Cretaceous Res. $6235-259$

Olmez I, Finnagan D L and Zoller W H 1986 Iridium emissions from Kilauea volcano; J. Geophys. Res. 91 653-663

Orth C J, Attrep M Jr, Quintana L R 1990 Iridium abundance patterns across bio-event horizons in the fossil record, In: Global catastrophes in Earth History; Geol. Soc. Amer. Spec. Pap. 247 45-60

Ray J S 1997 Stable and radioisotopic constraints on the evolution of Mesozoic carbonatite-alkaline complexes of India; Ph.D. Thesis, M.S. University of Baroda, Baroda, India 186pp.

Ray J S and Pande K 1999 Carbonatite alkaline magmatism associated with continental flood basalts at stratigraphic boundaries: cause for mass extinctions; Geophys. Res. Lett. 26 1917-1920

Roedder P L 1973 Fluid inclusions from the fluorite deposits associated with carbonatites of Amba Dongar India and Okurusu, South West Africa; Trans. Inst. Min. Metall. 82, B 33-39

Schmidt G and Pernicka E 1994 The determination of platinum group elements (PGE) in target rocks and fall-back material of the Nordlinger Ries impact crater, Germany; Geochim. Cosmochim. Acta 57 4851-4859

Shukla A D, Bhandari N, Kusumgar S, Shukla P N, Ghevariya Z G, Gopalan K and Balaram V 2001 Geochemistry and magnetostratigraphy of Deccan flows at Anjar, Kutch; Proc. Indian Acad. Sci. (Earth Planet. Sci.) (this issue, pages $111-132$ )

Sukheswala R N and Udas G R 1964 The carbonatite of Amba Dongar, India: some structural considerations; XXII Int. Geol. Congr. India, II, 1 - 13

Toutain J P and Meyer G 1989 Iridium-bearing sublimates at a hot-spot volcano (Piton de la Fournaise, Indian Ocean); Geophys. Res. Lett. 161391 - 1394

Venkatesan T R, Pande K and Ghevariya Z G $1996{ }^{40} \mathrm{Ar}-$ ${ }^{39} \mathrm{Ar}$ ages of Anjar Traps, western Deccan Province (India) and its relation to Cretaceous-Tertiary boundary events; Curr. Sci. 70 990-996

Venkatesan T R and Pande K 1996 A Review of ${ }^{40} \mathrm{Ar}^{39}{ }^{39} \mathrm{Ar}$ ages from the Western Ghats, Deccan Trap Province, India: Implication for K/T events. In: Nat. Symp. Deccan Flood basalts, India; (eds.) S S Deshmukh and K K K Nair; Gondawana Geol. Mag. Spl.Vol. 2 321-328

Venkatesan T R, Pande K and Gopalan K 1993 Did Deccan volcanism pre-date the Cretaceous/Tertiary transition?; Earth Planet. Sci. Lett. 119 181-189 
Viladkar S G 1996 Geology of the carbonatite-alkalic diatreme of Amba Dongar, Gujarat, Gujarat Mineral Development Corporation, Ahmedabad, 74pp

Wood S A 1987 Thermodynamic calculations of the volatility of platinum group elements (PGE): The PGE content of fluids at magmatic temperatures; Geochim. Cosmochim. Acta 51 3042-3050

Zoller W H, Parrington J R and Phelan Kotra J M 1983 Iridium enrichment in air-borne particulates from Kilauea volcano; Science 222 1118-1121

MS received 28 January 2000; revised 24 December 2000 